\title{
Allocation of Education Budget in Indonesia
}

\author{
Agung Saputra \\ State Administration Program, Social and Political Sciences Faculty, University of Muhammadiyah Sumatera Utara \\ (UMSU), Medan, Indonesia \\ arkapa68@gmail.com
}

\begin{abstract}
Education is considered to have a very important role in promoting the civilization of a nation. Good quality education can encourage the creation of a quality society, creative and productive until finally able to achieve welfare. Through this national education system, the government should be able to ensure equal distribution of educational opportunities, as well as the relevance and efficiency of education management to face challenges in line with the changing demands of local, national and global life. The budget allocation system for education in Indonesia is heavily influenced by government policies. Education financing depends on the management of educational institutions, but budget allocations used must conform to national financing standards. Education in Indonesia, implemented in accordance with educational policies that regulate the national education system, as well as the allocation of $20 \%$ education funding obtained from the state budget and APBD.
\end{abstract}

Keywords: education; budget; government policy; teachers

\section{INTRODUCTION}

It is necessary to reform the education in a planned, directed and sustainable manner. As mandated by the 1945 Constitution, Article 31 Paragraph (3) which reads: "The Government shall undertake and organize a national education system that promotes faith and piety and noble character in the framework of the intellectual life of the nation," and paragraph (5) which reads: "The government promotes science knowledge and technology by upholding the values of religion and national unity for the advancement of civilization and the welfare of mankind. " 
Education Function Article 3 of Law Number 20 Year 2003 on National Education System, states that national education function to develop the ability and form the character and civilization of a dignified nation in order to educate the nation. In the formulation of Article 3 of Law Number 20 Year 2003 on the National Education System, it contains four functions that must be actualized by education, namely: (1) the function of developing the ability of learners, (2) the function of forming a dignified nation's character, (3) the function of developing a dignified nation civilization, and (4) the intellectual function of the nation's life. Noeng Muhadjir (1987: 20-25) mentions that, as an educational institution carrying three functions. First, education serves to foster the creativity of learners. Second, education serves to pass on the values to learners; and Third, education serves to improve the productive work skills of learners. Education is basically related to various aspects of life human beings, both individually and socially. Education is not just change into clever or make the human child free from ignorance. Education is broader than that. In the great idea of education in our country for example is to educate the life of the nation and realize the whole Indonesian human beings. So education has the main purpose of which involves the participation of various parties, so that able to realize social function and enlightenment idea for society in order educated and civilized, to be ready to face the challenges of globalization. The education sector is one of the most important sectors implemented in realizing the success of development. The essence of educational development and Indonesia is the organization education aimed at poor society low income.

This is in accordance with the views and philosophy of life of the Indonesian people known as principle cooperativeness, that education is the right for every citizen. Thus, every citizen must have access to a proper education. Education is a variable that determines the quality of human resources of a nation. So it is the responsibility of the government to ensure the implementation of education with good quality/quality.

\section{REVIEW OF LITERATURE}

Based on Law Number 20 of 2003 on the National Education System, it is mandated that the central government and regional governments are obliged to provide services and facilities, as 
well as ensure the implementation of quality education for every citizen without discrimination. Quality education is an expensive investment. Public awareness to bear the cost of education will essentially give a power to society to be responsible for the implementation of education. Implementation of PP no. 19 Year 2005 brings implications for the need to develop financing standards that include standardization of education cost components covering operational costs, investment costs and personal costs. In accordance with the amended 1945 Constitution, the State of Indonesia gives a mandate to the government to set education budget 20 percent of the state budget as stated in Article 31 Paragraph 4. Implementation of PP no. 19 Year 2005 has implications for the need to develop financing standard which includes standardization of education cost component covering operational cost, investment cost and personal cost. Furthermore, it is stated that standard of education unit cost is determined by Minister Regulation based on proposal of National Education Standards Agency (BSNP). This education financing standard is expected to be a reference in the implementation of education in every elementary school (SD), Primary School (SMP), and Senior High School (SMA) throughout Indonesia. Implementation of education is closely related to financing. In accordance with the mandate of the Law, each year has proclaimed the allocation of education budget of $20 \%$ of the total state budget of revenues and expenditure (APBN), as well as the local government each year set a budget for education both for teachers salaries and salaries of educational personnel in the region.

\section{DISCUSSION}

Since the enactment of UU Sisdiknas 2003, there has been a gradual increase of education budget. In the calculation, the $20 \%$ amount will be achieved in 2009. The calculation and technical details of the $20 \%$ national education budget are the total APBN in central, $20 \%$ of provincial APBD, and 20\% in APBD County town. The education budget is the budget allocation for educational functions budgeted through state ministries / agencies, the allocation of education budgets through transfers to regions, and the allocation of education budgets through financing expenditures, including the salaries of educators, but excluding official education budgets, to finance the provision of education which is the responsibility the Government replied. The 
percentage of education budget is the ratio of education budget allocation to total state budget allocation. As is known in Article 31 paragraph 4 of the 1945 Constitution explicitly stated as follows, "The State prioritizes the State Budget (APBN) and the Regional Budget (APBD) to meet the needs of national education." In the law is clearly visible that education funding should prioritize education, as the progress of a country is seen from the advance of education. The quality of a country is also seen from the quality of its education. Based on APBN data from 2010 to 2015, the allocation of education budget has fulfilled the mandate of the 1945 Constitution that is at least $20 \%$ of state expenditure. The allocation of education budget is done by three channels, that is:

a. Education Budget allocation through central government expenditure increased from Rp96.5 trillion in 2010 to Rp154.2 trillion in 2015. The allocation of education budget to Central Government is used, among others, to provide scholarships for underprivileged students, rehabilitation of space classrooms, construction of new school units and new classrooms, as well as construction of supporting infrastructure and provision of teacher professional allowances.

b. The allocation of education budget by transfer to the region among others consists of part of the budget allocated to the budget.

c. Education budget through financing expenditure, hereinafter referred to as national education development fund (DPPN) consists of endowment funds for education and reserve fund of education, where the fund is managed by BLU in education, namely Institution of Education Fund (LPDP), which is a satker from the Ministry of Finance. The legal basis for the Management of the DPPN is regulated by Minister of Finance Regulation No. 238 / PMK.05 /2010 on Procedures for the Supply, Liquidation, Management and Accountability of the Endowment Fund and the Reserve Fund for Education.

Efforts to improve the quality of education in Indonesia through budget allocation, then the government should be able to make a priority for improving the quality of Indonesian people. The realization of education budget that reaches $20 \%$ of total state budget should be realized by the government soon. Do not until this huge budget is not felt by the people. The establishment of a standardized education system and should not change at every turn of the minister should be a 
government target. Completeness of facilities as well as equality of education quality for every citizen, especially areas far from the city center. Such areas should be the focus of the government because so many people do not get their right to education. Improving the quality of educators must also be considered by the government. Do not let the teachers who teach the prospective leaders of this nation are just people who do not understand what they teach. Here are some things that must be done by the government to immediately solve human resource problems in Indonesia The allocation of education budget aims to improve the quality of national education, then all the funds must be absorbed for the development of education effectively and efficiently. In the implementation of this budget allocation is also associated with education financing standards that have been set in national education financing standard policies.

Nanang (2012), that funding is basically classified into two models, namely:

\section{a. Flat Grand Model}

Using a fund distribution system, in which all districts receive the same amount of funds for each pupil, does not show differences in local capacity. Areas with rich resources and areas where natural resources do not support (poor), will receive the same amount in education budget allocation.

\section{b. Equalization Model}

Due to the ability to pay of the community, it means that the poor need to receive financial aid compared to the higher incoment people. Therefore, poor schools will have equal opportunities with other schools, meaning that each region will receive a different budget allocation depending on the ability of the region. Thus, in allocating this education budget required a mature planning system and able to formulate the national financing system. Ardi (2011) explains that the educational financing model has two sides namely the revenue and expenditure side. 1) the revenue budget is the income earned annually by schools from various official sources and received on a regular basis. For public primary schools, generally have revenue budgetary sources comprising central government, local government, local communities, parents and other sources; 2) expenditure budget is the amount of money spent each year for the benefit of education in the School. School expenditure is largely determined by the components whose numbers and proportions vary between one school and another. 


\section{CONCLUSION}

The budget allocation system for education in Indonesia is heavily influenced by government policies. Education financing depends on the management of educational institutions, but budget allocations used must conform to national financing standards. Education in Indonesia, implemented in accordance with educational policies that regulate the national education system, as well as the allocation of $20 \%$ education funding obtained from the state budget and APBD. One of the programs that is the result of the allocation of the education budget is the BOS (School Operational Cost) fund which aims to cover the book prices and other costs. Another program is the enforcement of free schools, this should also be implemented with the provision of educational policy, although free does not mean having a low quality of education .Through the allocation of education budget in Indonesia, although not maximal but has been able to help the community to get a decent and quality education. This allocation has also helped the welfare of teachers and education personnel to live more worthy so as to provide quality education for the community.

\section{REFERENCES}

Anggara, Sahya. 2012.Ilmu Administrasi Negara, Bandung: Pustaka setia.

Arikunto, Suharsimi. 2003. Manajemen Penelitian. Jakarta: Rinata Cipta

Azheri, Busyra. 2011. Corporate Social Responsibility Dari Voluntary Menjadi Mandatory, Jakarta: Rajawali Pers

Chapra, Umer. dan Habib Ahmed. 2008. Corporate Governance Lembaga Keuangan Syariah, Jakarta: Bumi Aksara

Effendi, Muh. Arief. 2009. The Power of Good Corporate Governance, Jakarta: Salemba Empat. Faisal, Sanafiah.2005. Format-Format Penelitian Sosial, Jakarta: PT.Raja Grafindo Persada.

Nanang, Fattah. 2012. Analisis Kebijakan Pendidikan. Bandung; Remaja Rosdakarya.

Suyanto, Bagong dan Sutinah. 2005. Metode Penelitian Sosial:Berbagai Alternatif dan Pendekatan. Jakarta: Prenada Media 
Syafi'i, Inu Kencana. 2006. Ilmu administrasi Publik, Jakarta: PT Asdi Mahasatya.

Syafri, Wirman. 2012. Studi Tentang Administrasi Publik,Jakarta: Erlangga.

Undang-undang Nomor 20 Tahun 2003 tentang Sistem Pendidikan Nasional

Untung, Hendrik Budi. 2009. Corporate Social Responsibility, Jakarta: Sinar Grafika

Zuriah, Nurul. 2005. Metodologi Penelitian Sosial dan Pendidikan,Jakarta: Bumi Aksara. 